\title{
Cloning, Purification, and Characterization of Recombinant Human Extracellular Superoxide Dismutase in SF9 Insect Cells
}

\author{
Pravesh Shrestha', Ji-Hye Yun', Woo Taek Kim², Tae-Yoon Kim ${ }^{3, *}$, and Weontae Lee ${ }^{1, *}$
}

\begin{abstract}
A balance between production and degradation of reactive oxygen species (ROS) is critical for maintaining cellular homeostasis. Increased levels of ROS during oxidative stress are associated with disease conditions. Antioxidant enzymes, such as extracellular superoxide dismutase (EC$S O D)$, in the extracellular matrix (ECM) neutralize the toxicity of superoxide. Recent studies have emphasized the importance of EC-SOD in protecting the brain, lungs, and other tissues from oxidative stress. Therefore, EC-SOD would be an excellent therapeutic drug for treatment of diseases caused by oxidative stress. We cloned both the full length (residues 1-240) and truncated (residues 19-240) forms of human EC-SOD (hEC-SOD) into the donor plasmid pFastBacHTb. After transposition, the bacmid was transfected into the Sf9-baculovirus expression system and the expressed hEC-SOD purified using FLAG-tag. Western blot analysis revealed that hEC-SOD is present both as a monomer (33 kDa) and a dimer (66 kDa), as detected by the FLAG antibody. A water-soluble tetrazolium (WST-1) assay showed that both full length and truncated hEC-SOD proteins were enzymatically active. We showed that a potent superoxide dismutase inhibitor, diethyldithiocarbamate (DDC), inhibits hEC-SOD activity.
\end{abstract}

\section{INTRODUCTION}

The body produces reactive oxygen species (ROS) as a result of aerobic respiration and substrate oxidation. These ROS play several important roles in cell signaling, defense against micro-

\footnotetext{
${ }^{1}$ Department of Biochemistry, College of Life Sciences and Biotechnology, ${ }^{2}$ Department of Systems Biology, College of Life Science and Biotechnology, Yonsei University, Seoul 120-749, Korea, ${ }^{3}$ Department of Dermatology and Catholic Research Institute of Medical Science, College of Medicine, The Catholic University of Korea, Seoul 137-040, Korea

*Correspondence: wlee@spin.yonsei.ac.kr (WL); tykimder@catholic.ac.kr (TYK)
}

Received 8 October, 2015; revised 23 November, 2015; accepted 4 December, 2015; published online 25 February, 2016

Keywords: extracellular matrix (ECM), human extracellular superoxide (hEC-SOD), LC-MS/MS, reactive oxygen species (ROS), sodiumdiethyldithiocarbamate bial infections, maintaining cellular homeostasis, and lipid oxidation. However, high levels of ROS are observed during oxidative stress and, if unchecked, can lead to cardiovascular diseases (e.g., heart failure, hypercholesterolemia, arthrosclerosis, hypertension, and diabetes). Enzymes, such as superoxide dismutase (SOD), help to neutralize the harmful effect of these ROS. SOD converts free radicals (ROS) into less harmful molecules, viz., hydrogen peroxide $\left(\mathrm{H}_{2} \mathrm{O}_{2}\right)$ and oxygen $\left(\mathrm{O}_{2}\right)$, which are further metabolized by relevant cellular pathways.

Based on its distribution, SOD is mainly categorized into three forms: SOD1 (Cu/Zn-SOD, a homodimer) is localized in the cytosol, SOD2 (Mn-SOD, a homodimer/tetramer) is found in the mitochondria, and SOD3 (EC-SOD, a tetramer) is localized in the extracellular space (Beyer et al., 1991; Zelko et al., 2002). Extracellular superoxide dismutase (EC-SOD)/SOD3 catalyzes dis-mutation of the superoxide $\left(\mathrm{O}_{2}^{-}\right)$radical into either ordinary molecular oxygen $\left(\mathrm{O}_{2}\right)$ or hydrogen peroxide $\left(\mathrm{H}_{2} \mathrm{O}_{2}\right)$. Blood vessel walls, kidneys, the uterus, and lungs usually contain high SOD3 levels (Nozik-Grayck et al., 2005; Petersen et al., 2005) SOD3 is synthesized by vascular smooth muscle cells, which subsequently binds to the heparan sulfate on the endothelial cell surface, from where it is internalized by the endothelial cells (Ohta et al., 1994). SOD3 prevents destruction of the NO • from superoxide anions in the extracellular space (Carlsson et al., 1995), which is necessary to stimulate smooth muscle relaxation (Oury et al., 1996a). Furthermore, SOD3 is the only antioxidant enzyme in the extracellular matrix (ECM) that neutralizes superoxide toxicity. It has been proposed that EC-SOD protects the brain, lungs, and other tissues from oxidative stress (Oury et al., 1996b). For example, SOD3 plays an important role in hypoxic lung injury, bleomycin toxicity, viral pneumonia, and asbestosis (Bowler et al., 2002; 2004; Folz et al., 1999; Mamo et al., 2004; Oury et al., 2002; Tan et al., 2004). In both the brain and kidney, SOD3 has protective effects related to ischemia/reperfusion injury (Demchenko et al., 2002), while hypoxic activation of erythropoietin in the kidney also requires SOD3 (Suliman et al., 2004).

The potential of SOD3 as a therapeutic drug for various diseases has led to several attempts at expression and purification of EC-SOD in Escherichia coli (He et al., 2002; Ryu et al., 2008), insect cells (He et al., 2002), Pichia pastoris (Chen et al., 2006), $\mathrm{CHO}$ cells (Tibell et al., 1987), Lactobacillus casei (Chen et al., 2013), and transgenic chicken (Byun el al., 2013). However, expression of EC-SOD has been limited by factors such as inclusion bodies, insufficient yield, inhomogeneity, and lack of activity. 
Here, we engineered FLAG-tagged full length (residues 1240; hEC-SOD') and truncated (residues 19-240; hEC-SOD ${ }^{\text {tr }}$ ) forms of human extracellular superoxide dismutase (SOD3/ hEC-SOD) and expressed these in the Spodoptera frugiperda (Sf9) insect cell system. We then purified the recombinant hECSOD, using anti-DYKDDDK G1 affinity resin as a soluble and uniformly active form of the enzyme. Furthermore, diethyldithiocarbamate (DDC), a potent superoxide dismutase inhibitor was also tested which was able to inhibit hEC-SOD activity. Our study forms the basis for developing active and homogenous hEC-SOD as a therapeutic drug using the Sf9 expression system.

\section{MATERIALS AND METHODS}

\section{Plasmid construction of hEC-SOD}

Nucleotide sequences encoding the full length (residues 1-240) and truncated/mature form (residues 19-240) of hEC-SOD were first amplified by PCR, using primers encoding a FLAGtag (DYKDDDDK) and PreScission cleavage enzyme recognition sequence (LEVLFQG) at the N-termini, using EcoRI and $X$ hol restriction enzyme sites. The amplified DNA fragments were inserted into the pFastBacHTb ${ }^{\mathrm{TM}}$ vector (Invitrogen, USA) to encode a (His) $)_{6}-$ FLAG-tagged-PreScission cleavage site fusion of the hEC-SOD protein. After cloning, sequences of both constructs were confirmed by sequencing the plasmids (Macrogen Co.).

\section{Insect cell transfection and expression}

Cloned plasmids were transformed into $\mathrm{DH} 10 \mathrm{Bac}^{\mathrm{TM}}$ Escherichia coli. Transposition into the bacmid was performed as described in the protocol of the Bac-to-Bac ${ }^{\circledR}$ Baculovirus Expression System. 1000ug of recombinant bacmid DNA containing hEC-SOD ${ }^{\mathrm{f}}$ and $\mathrm{hEC}-\mathrm{SOD}^{\mathrm{tr}}$ were transfected into Sf9 cells $(0.5 \times$ $10^{6}$ cells $/ \mathrm{ml}$ ) using $8 \mu \mathrm{l}$ of Cellfectin ${ }^{\circledR}$ II Reagent (Invitrogen ${ }^{\mathrm{TM}}$ by Life Technologies) and $100 \mu \mathrm{l} \mathrm{CCM3} \mathrm{media} \mathrm{(HyClone}{ }^{\mathrm{TM}}$ ), after which cells were incubated for 3 days at $27^{\circ} \mathrm{C}$. Virus stock amplification was performed using the Bac-to-Bac Baculovirus Expression method as per the manufacturer's instructions. Sf9 cells $\left(2 \times 10^{6}\right.$ cells $\left./ \mathrm{ml}\right)$ were infected with P3 virus at an optimal multiplicity of infection (MOI: number of virus particles/number of cells) of 3 in Insectagro ${ }^{\circledR}$ media (Corning) and incubated at $27^{\circ} \mathrm{C}$ for $72 \mathrm{~h}$ before harvesting $\left(2500 \mathrm{rpm}\right.$ at $\left.4^{\circ} \mathrm{C}\right)$.

\section{Purification of recombinant $h E C-S O D$}

Frozen cell pellets were thawed and resuspended at $4^{\circ} \mathrm{C}$ for 30 min using lysis buffer (50 mM Tris- $\mathrm{HCl}, \mathrm{pH} 7.4,150 \mathrm{mM} \mathrm{NaCl}$, $10 \mathrm{mM} \beta$-mercaptoethanol, an EDTA-free protease inhibitor cocktail (Roche), $0.5 \%(\mathrm{v} / \mathrm{v})$ Nonidet ${ }^{\circledR} \mathrm{P}-40$, and $2 \mathrm{mM}$ phenylmethylsulfonylfluoride [PMSF]). The lysate was subjected to ultracentrifugation at $15,000 \mathrm{rpm}$ for $30 \mathrm{~min}$ at $4^{\circ} \mathrm{C}$ and the supernatant was loaded onto the GenScript Anti-DYKDDDK G1 Affinity resin (Cat. No. L00432). FLAG-tagged hEC-SOD was then purified following the protocol provided by GenScript. Purified hEC-SOD was simultaneously concentrated to $0.3 \mathrm{mM}(9$ $\mathrm{mg} / \mathrm{ml}$ ). The final buffer was exchanged to phosphate-buffered saline (PBS) using $10 \mathrm{kDa}$ Amicon Ultra centrifugal filter tube (Millipore).

\section{Western blot analysis}

Whole cell expressed in Sf9 cells, the soluble fraction obtained after lysis, and purified hEC-SOD ${ }^{f}$ and hEC-SOD ${ }^{\text {tr }}$ were mixed with $5 \times$ sample buffer and resolved by $12 \%$ SDS-PAGE at 120 $\mathrm{V}$ for $2 \mathrm{~h}$. Western blot analysis was performed as described by
Yun et al. (2005). Monoclonal anti-FLAG M2 alkaline phosphatase antibody (Sigma), and SIGMAFAST BCIP/NBT (Sigma) were used for visualization. A mouse monoclonal primary antibody was used at a dilution of 1:2000 to detect the FLAGtagged recombinant hEC-SOD.

Anti-Superoxide Dismutase 3 antibody $\left(\right.$ abcam $^{\circledR}$ - ab21974) was used to detect native form of hEC-SOD before and after DTT titration. A secondary anti-rabbit antibody was used at a dilution of 1:5000 to detect the recombinant hEC-SOD. The $12 \%$ Native PAGE was run at $90 \mathrm{~V}$ for $3 \mathrm{~h}$ at $4^{\circ} \mathrm{C}$ to avoid denaturing the protein.

Circular dichroism (CD) and fluorescence spectroscopy CD spectra of both the hEC-SOD ${ }^{f}$ and hEC-SOD ${ }^{\text {tr }}$ were measured in PBS buffer at $\mathrm{pH} 7.4$ on a JASCO J-815 spectropolarimeter (Jasco, Japan), calibrated with ammonium D-10-camphorsulfonate at $290 \mathrm{~nm}$ and equipped with a thermostatically controlled cell holder attached to a water bath with an accuracy of $\pm 0.1^{\circ} \mathrm{C}$. The $\mathrm{CD}$ spectra were measured in the presence and absence of $50 \mu \mathrm{M} \mathrm{Cu} / \mathrm{Zn}$ buffer of $\mathrm{pH} 7.4$. Inbuilt secondary structure prediction (Yang's and Reed's Reference) was used to calculate the tendency for taking on a helical to $\beta$-sheet secondary structure upon $\mathrm{Cu} / \mathrm{Zn}$ addition.

Fluorescence assay was performed at $298 \mathrm{~K}\left(25^{\circ} \mathrm{C}\right)$ using an LS55 spectrofluorophotometer (Perkin Elmer, USA). Both hECSOD forms $(10 \mu \mathrm{M})$ and an inhibitor, Na-DDC $(1 \mathrm{mM})$, were prepared in PBS (pH 7.4). The fluorescence of hEC-SOD (Ex. $280 \mathrm{~nm}$ ) was collected from $270 \mathrm{~nm}$ to $450 \mathrm{~nm}$ (data shown from $300 \mathrm{~nm}$ to $450 \mathrm{~nm}$ ) upon titrating with $5-\mu \mathrm{M}$ increments of $\mathrm{Na}-\mathrm{DDC}(0 \mu \mathrm{M}$ to $100 \mu \mathrm{M})$, with a 1 -min incubation time for each increment.

\section{DTT titration of purified hEC-SOD}

Purified hEC-SOD ${ }^{f}$ and hEC-SOD ${ }^{\mathrm{tr}}$ were incubated for $60 \mathrm{~min}$ with and without $10 \mathrm{mM}$ DTT in PBS buffer, at $4^{\circ} \mathrm{C}$. Protein samples were centrifuged at $14,000 \mathrm{rpm}$ at $4^{\circ} \mathrm{C}$ to remove any aggregates. hEC-SOD was also analyzed by size exclusion chromatography(SEC) using a HiLOAD ${ }^{\mathrm{TM}} 10 / 300$ Superdex $^{\mathrm{TM}}$ 200 (GE Healthcare) after injection of a $500-\mu l$ sample. The protein was eluted at $4^{\circ} \mathrm{C}$, at a flow rate of $0.5 \mathrm{ml} / \mathrm{min}$, using PBS ( $\mathrm{pH} \mathrm{7.4)} \mathrm{as} \mathrm{the} \mathrm{mobile} \mathrm{phase,} \mathrm{with} \mathrm{and} \mathrm{without} 10 \mathrm{mM}$ DTT.

\section{Activity assay of $h E C-S O D$}

The activity of the purified hEC-SOD ${ }^{f}$ and hEC-SOD ${ }^{\text {tr }}$ was assayed in vitro using the SOD Assay Kit WST-1 (Dojindo Laboratories) (Tan and Berridge, 2000). This assay is based on the detection of a water-soluble formazan dye that is formed upon reduction of water-soluble tetrazolium salt, WST-1, by the superoxide anion. Purified EC-SOD $(25 \mu \mathrm{M})$ was incubated with the reaction mixture, including a final concentration of $0.05 \mathrm{M}$ sodium carbonate ( $\mathrm{pH} 9.0), 1.0 \mathrm{U}$ catalase, $10^{-4} \mathrm{M}$ xanthine, 5.6 $\times 10^{-5} \mathrm{M}$ WST- 1 , and $3.7 \mathrm{mU}$ xanthine oxidase, at $37^{\circ} \mathrm{C}$ in the cell compartment of the spectrophotometer, and the sample was spectrophotometrically monitored at $450 \mathrm{~nm}$ at various time points, up to $30 \mathrm{~min}$.

\section{SOD Activity calculation}

One unit of SOD is defined as the amount of the enzyme in 20 $\mu \mathrm{l}$ of sample solution that inhibits the reduction reaction of WST-1 with superoxide anion by $50 \%$.

1DE band of hEC-SOD were excised from the preparative gel, 
and the spots were transferred into each $1.5 \mathrm{ml}$ tube. The band was washed with $100 \mu \mathrm{l}$ of distilled water; then, $100 \mu \mathrm{l}$ of 50 $\mathrm{mM} \mathrm{NH}_{4} \mathrm{HCO}_{3}(\mathrm{pH} 7.8)$ and acetonitrile $(6: 4)$ were added to the band and shook for in $10 \mathrm{~min}$. This process was repeated at least three times until the Coomassie brilliant blue G250 dye disappeared. The supernatant was decanted, and the band was dried in speed vacuum concentrator (LaBoGeneAps, Denmark) for $10 \mathrm{~min}$. Reduction of the sample was performed in $10 \mathrm{mM}$ dithiothreitol/25 mM NH $\mathrm{mHCO}_{3}(\mathrm{pH}$ 8.0) for over 30 $\min$ at $56^{\circ} \mathrm{C}$. The solution was decanted and the band was stored at room temperature in $55 \mathrm{mM}$ iodoacetamide in the dark for $20 \mathrm{~min}$. The solution was decanted and then digested with sequence-grade modified trypsin (Promega Co., USA) (enzyme to substrate ratio $=1: 50$ ) at $37^{\circ} \mathrm{C}$ with shaking for $16 \mathrm{~h}$.

\section{Deglycosylation}

After Trypsin digestion, $1 \mathrm{ul}$ of $\mathrm{NH}_{4} \mathrm{HCO}_{3}$ buffer $(10 \mathrm{mM}, \mathrm{pH} 8.0)$ with $0.5 \mathrm{U}$ PNGase $\mathrm{F}$ enzymes was added and shook at $37^{\circ} \mathrm{C}$ for $6 \mathrm{~h}$ for glycopeptide deglycosylation. The $\mathrm{N}$-linked site was identified on the basis of the difference in mass from the native sequence associated with conversion of Asn to Asp (0.98 Da) after PNGase F treatment.

\section{LC-MS/MS peptide analysis and database searching}

Nano LC-MS/MS analysis of the purified hEC-SOD ${ }^{f}$ and hEC$S O D^{\text {tr }}$ was performed with an Easy n-LC (Thermo Fisher, USA). The capillary column used for LC-MS/MS analysis $(150 \mathrm{~mm} \times$ $0.075 \mathrm{~mm}$ ) was obtained from Proxeon (Denmark) and the slurry packed in-house with a $5-\mu \mathrm{m}, 100-A$ pore size Magic $\mathrm{C} 18$ stationary phase resin (Michrom BioResources, USA). LTQOrbitrap mass spectrometry (Thermo Fisher, USA) was used for peptide identification. Mass spectra were acquired using data-dependent acquisition with a full mass scan $(350-1200 \mathrm{~m} / \mathrm{z})$ followed by five MS/MS scans. For MS1 full scans, the Orbitrap resolution was 30,000 and the AGC was $2 \times 10^{5}$. For MS/MS in the LTQ, the AGC was $1 \times 10^{4}$. The mascot algorithm (Matrixscience, USA) was used to identify peptide sequences present in a protein sequence database. Database search criteria were: taxonomy; target protein (hEC-SOD ${ }^{f}$ and $h E C-S O D^{\natural r}$ ), fixed modification; carboxyamidomethylated at cysteine residues; variable modification; oxidized at methionine residues, deamidated at asparagine residue, maximum allowed missed cleavage of 2 , MS tolerance of $10 \mathrm{ppm}, \mathrm{MS} / \mathrm{MS}$ tolerance of $0.8 \mathrm{Da}$. The peptides were filtered with a significance threshold of $\mathrm{P}<0.05$.

\section{RESULTS}

\section{Construction and bacmid preparation of the expression} plasmid

The coding sequence of hEC-SOD was amplified by PCR from cDNA using primers that included both the $\mathrm{N}$-terminal signal peptide and the C-terminal heparin-/heparin sulfate-binding

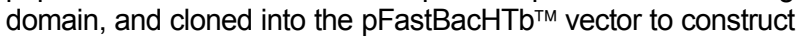
an expression plasmid, as described in materials and methods section (Fig. 1). The cloned plasmids of both hEC-SOD ${ }^{f}$ and hEC-SOD ${ }^{\text {tr }}$ contained an N-terminal Flag-tag, and a PreScission cleavage site, followed by the hEC-SOD sequence, as confirmed by sequencing (Figs. 1A-1D). The cDNA was transpositioned into the bacmid in E. coli using a blue/white colony selection method (Invitrogen ${ }^{\mathrm{TM}}$ by Life Technologies). Transposition occurred by transforming the donor plasmid into the $E$. coli DH10Bac, which contained the Bacmid and helper phage. Recombinant bacmid DNA was isolated by ethanol precipitation and the concentration determined by nanodrop. Primary se- quence with secondary structures of hSOD, metail ion binding and glycosylation site are shown in Fig. 1E.

\section{Expression and purification of hEC-SOD in Sf-9 cells}

Transposition of the recombinant vector to the baculovirus DNA in $E$. coli was followed by preparation of high-titer virus stocks. This recombinant baculovirus DNA was infected into Sf9 cells to amplify the virus stock from a P1 to P3 virus titer. For hECSOD expression, $300 \mathrm{ml} \mathrm{Sf9}$ cells were infected with $\mathrm{P} 3$ virus at an $\mathrm{MOI}$ of 3.0 and harvested $72 \mathrm{~h}$ post-infection. The infection was confirmed by monitoring YFP (Yellow Fluorescence Protein/Green filter; Fig. 1F). hEC-SOD cDNA is expressed under the control of the polyhedrine promoter after recombinant baculovirus infection of Sf9 cells.

The cell pellet harvested after $72 \mathrm{~h}$ was resuspended in lysis buffer and purified using anti-DYKDDDK G1 Affinity Resin (section 2.3). Western blot analysis confirmed that the molecular weights of hEC-SOD ${ }^{f}$ and hEC-SOD ${ }^{\text {tr }}$ expressed in Sf9 cells were around $31 \mathrm{kDa}$ and $30 \mathrm{kDa}$, respectively, as expected (Figs. $1 \mathrm{G}$ and $1 \mathrm{H}$ ).

\section{Oligomerization of $h E C-S O D$}

To obtain the native form of hEC-SOD, we purified both hEC$S^{f} D^{f}$ and $h E C-S O D^{\text {tr }}$ without using reducing agents, such as DTT or $\beta$-mercaptoethanol. Purified proteins were then loaded onto HiLOAD ${ }^{\text {тм }} 10 / 300$ Superdex ${ }^{\text {Tм }} 200$ (GE Healthcare), previously calibrated with standard protein markers and equilibrated with PBS buffer, which resulted in elution of almost all injected proteins in the void volume, including some in the monomeric form (Fig. 2A). This confirmed that both hEC-SOD ${ }^{f}$ and hEC$S D^{t r}$ form octamer. To assess the possible effect of DTT on the oligomerization of hEC-SOD, $10 \mathrm{mM}$ DTT was added to the previously purified $\mathrm{hEC}-\mathrm{SOD}^{\mathrm{f}}$ and $\mathrm{hEC}-\mathrm{SOD}^{\mathrm{tr}}$, as described in materials and methods section. SEC of the DTT-treated hECSOD showed that the majority of the oligomeric hEC-SOD (both full length and truncated forms) shifted towards the monomeric fraction (Fig. 2A.), this was reconfirmed by running native page detected using anti-Superoxide Dismutase 3 antibody (Fig. 2B), a result of protein being reduced by excess DTT, as previously published (Bae et al., 2013).

Secondary structure determination by circular dichroism (CD) Circular dichroism experiments have been performed on both hEC-SOD ${ }^{f}$ and $h E C-S O D^{\text {tr }}$ to compare their secondary structure, using $20 \mu \mathrm{M}$ of protein in PBS (pH 7.4) at $25^{\circ} \mathrm{C}$ (Fig. 2C). Superimposing the $C D$ spectra of the full length and truncated form showed slight differences in the secondary structure. This may be because $h E C-S O D^{f}$ contains an extra N-terminal sequence that contribute to the difference in secondary structure. We assessed the effect of $\mathrm{Zn}^{2+;} \mathrm{Cu}^{2+}$, and $\mathrm{Zn}^{2+1} \mathrm{Cu}^{2+}(50 \mu \mathrm{M})$ on the secondary structure of $\mathrm{hEC}-\mathrm{SOD}$, and found no significant perturbation in the presence of metal ions (Figs. 2D and 2E). Prediction of the average secondary structure using Yang's prediction showed that hEC-SOD consisted of $36.4 \% \beta$-sheet and $17.9 \% \alpha$-helix, whereas hEC-SOD ${ }^{\text {tr }}$ consisted of $38.8 \% \beta$ sheet and $16.9 \% \alpha$-helix. The crystal structure of hEC-SOD from $E$. coli has been reported to be mainly composed of $\beta$ sheet, where the $\mathrm{N}$ - and $\mathrm{C}$-termini were not visible due to high flexibility (Antonyuk et al., 2009). Thus, we conclude that the hEC-SOD purified from Sf9 insect cells is mainly composed of $\beta$-sheet structures.

Enzyme activity of $h E C-S O D$

The enzymatic activity of hEC-SOD ${ }^{f}$ and hEC-SOD ${ }^{\text {tr }}$ was 
A

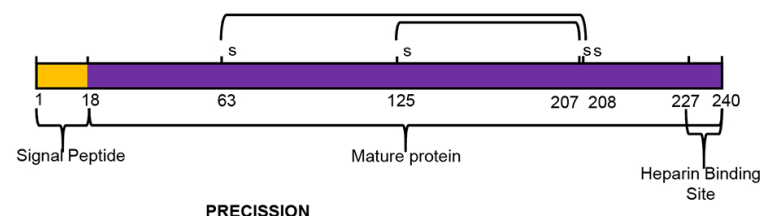

B

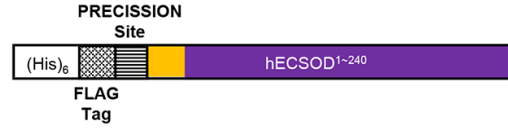

C

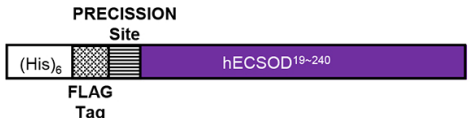

D

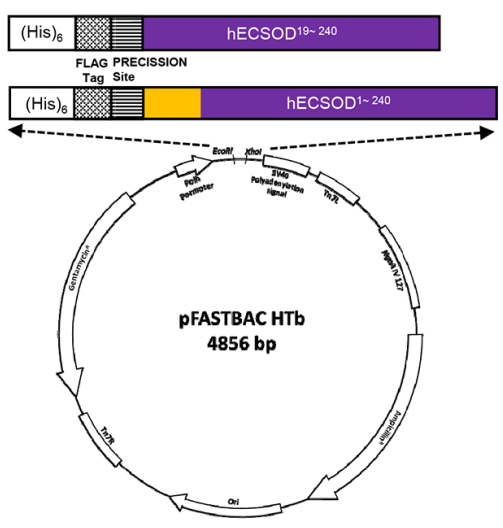

E

$\beta 1$

MLALLCSCLLLAAGASDAWTGEDSAEPNSPSAEWIRDMYAKVTEIWQEVMQRRDDDGTLHAACQVQPSATLDAAQPRVTG

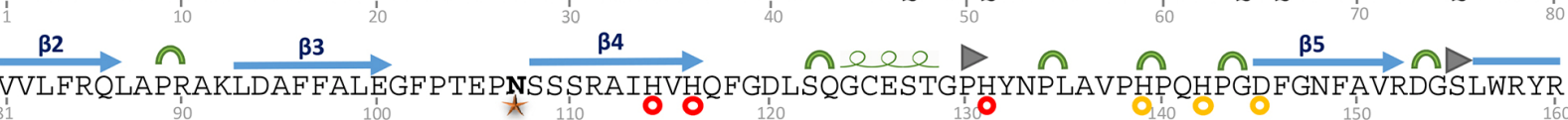

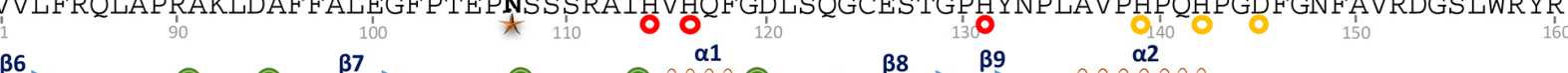

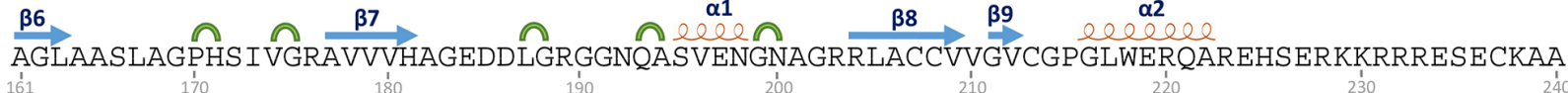

$\mathbf{F}$

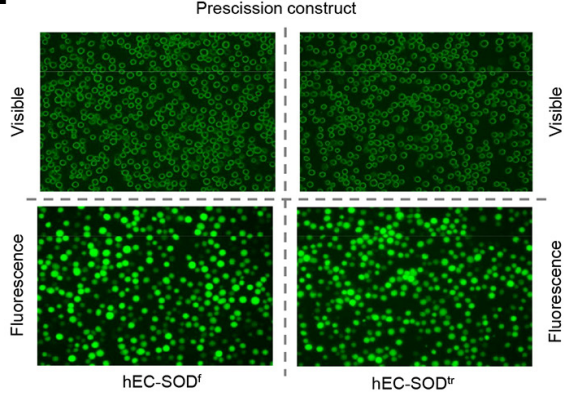

G

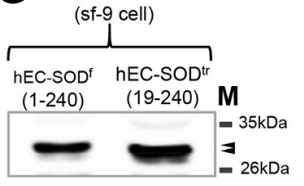

H

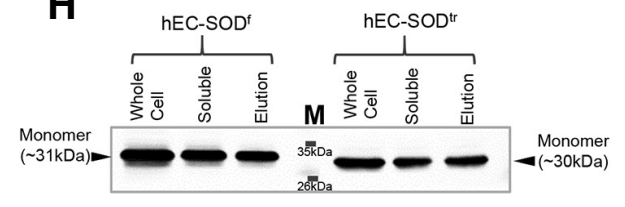

Fig. 1. Construct design, expression, and purification of hEC-SOD protein from Sf9 insect cells. (A) Schematic illustration of hEC-SOD. The protein consists of an $\mathrm{N}$-terminal signal peptide, mature protein, and a C-terminal heparin-binding site. The design of the construct of (B) hEC$\mathrm{SOD}^{f}$ and (C) hEC-SOD ${ }^{\mathrm{t}}$, with an N-terminal (His) 6 , a FLAG-tag and Precession enzyme site. (D) Map of the hEC-SOD expression vector, pFastBac HTB, containing the $\mathrm{pH}$ promoter, a pBR322 origin, and Ampicillin and Gentamycin resistance genes. A full length (residues 1-240) and truncated/mature form (residues 19-240) of hEC-SOD were first amplified by PCR, using primers encoding a FLAG-tag (DYKDDDDK) and PreScission cleavage enzyme recognition sequence (LEVLFQG) at the N-terminus, as well as EcoRI and Xhol restriction enzyme sites. (E) Secondary structure showing the glycosylation site and $\mathrm{Cu} / \mathrm{Zn}$ binding site of $\mathrm{hEC}-\mathrm{SOD}^{1-240}$ based on the crystal structure. PDB code: $2 \mathrm{JLP}$. [elel $\alpha$-helix, e e 3 -helix, $\longrightarrow \beta$-strand, $\cap$ Turn, $>\beta$-bridge, $\star N^{107}$ Glycosylation Site, $\mathbf{O}$ Cu binding site, $\mathrm{Zn}$ binding site]. (F) Transfected recombinant hEC-SOD expressed in Sf9 cells observed at the EGFP-excitation wavelength. (G) Western blot analysis of hEC-SOD expressed in Sf9 cells that had been incubated for 3 days at $27^{\circ} \mathrm{C}$, detected using an anti-FLAG antibody. (H) Western analysis of purified $\mathrm{hEC}-\mathrm{SOD}$ resolved by $12 \%$ SDS-PAGE and detected using an anti-FLAG antibody. The size of the expressed hEC-SOD and hEC$\mathrm{SOD}^{\mathrm{t}}$ was about 31 and $30 \mathrm{kDa}$ respectively. hEC-SOD': Lane 1, whole cell lysate; lane 2, soluble fraction; and lane 3, purified protein. hEC$\mathrm{SOD}^{\mathrm{t}}$ : Lane 5, whole cell lysate; lane 6, soluble fraction; and lane 7, purified protein. Lane 4, molecular marker.

measured in the presence of $\mathrm{Zn}^{2+} / \mathrm{Cu}^{2+}$ and $0.1 \%$ BSA (Tan and Berridge, 2000) as described in materials and methods section. The activities of purified hEC-SOD ${ }^{f}$ and hEC-SOD ${ }^{\text {tr }}$ from Sf9 cells were calculated to be $210 \mathrm{U} / \mathrm{ml}$ and $220 \mathrm{U} / \mathrm{ml}$, respectively (Figs. $3 \mathrm{~A}$ and $3 \mathrm{~B}$ ). This implies that both the full length and truncated form of hEC-SOD have enzymatic activity. DDC, a thiol-containing molecule known as a potent metal ion-chelating agent (Arnelle et al., 1997; Iqbal and Whitney, 1991), is an inhibitor of Cu-Zn SOD. DDC inhibits the detoxification of ROS and increases superoxide concentrations (Didion et al., 2001; Li et al., 2002). Since Cu-Zn SOD and hEC-SOD are both forms of SOD, we tested whether sodium-diethyldithiocarbamate trihydrate, Na-DDC (Sigma life science) also inhibits hEC-SOD. Data from a fluorescence assay showed that Na-DDC has a higher affinity for hEC-SOD than for hEC-SOD ${ }^{\mathrm{tr}}$. Dissociation constants $\left(K_{d}\right)$ were determined as $7.14 \times 10^{-6} \mathrm{M}$ for hEC-SOD ${ }^{f}$ and $34.17 \times 10^{-6} \mathrm{M}$ for hEC-SOD ${ }^{\text {tr }}$ (Figs. $3 \mathrm{C}$ and $3 \mathrm{D}$ ). Inhibition of both hEC-SOD ${ }^{f}$ and hEC-SOD ${ }^{\text {tr }}$ in the presence of $50 \mu \mathrm{M}$ $\mathrm{Na}-\mathrm{DDC}$ is shown in Fig. 3E.

\section{LC-MS analysis of $h E C-S O D$}

The details of hEC-SOD ${ }^{f}$ and hEC-SOD ${ }^{\text {tr }}$ analyzed using LC- 
A

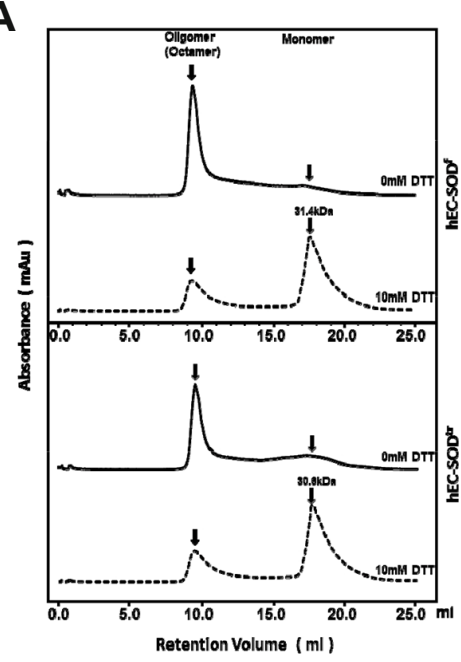

B

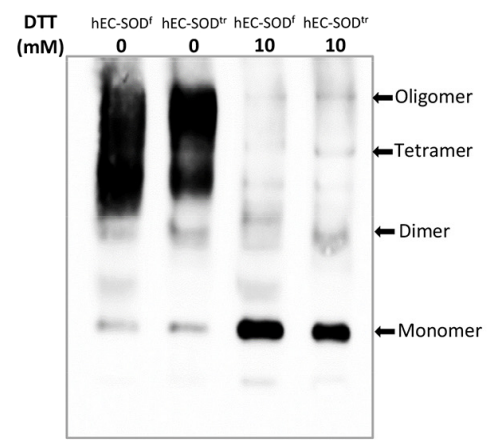

C

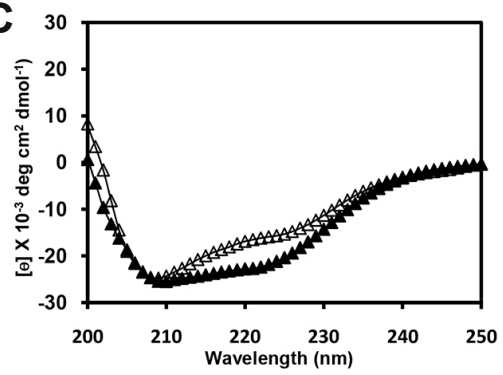

D
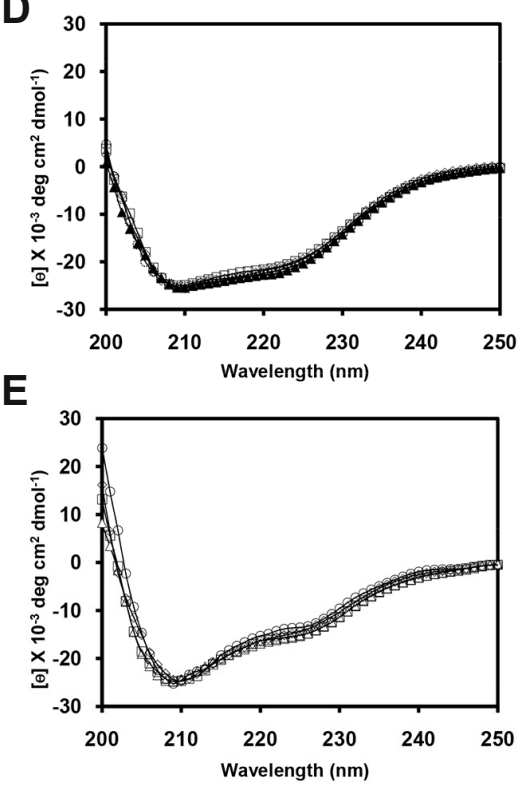

Fig. 2. Biophysical and biochemical characterization of purified hEC-SOD expressed in Sf9 cells. (A) Analytic size exclusion chromatography profile of the recombinant hEC-SOD (0 mM DTT and $10 \mathrm{mM}$ DTT), using a Superdex 200 column calibrated with standard protein markers. (B) Effect of DTT (0 to $10 \mathrm{mM}$ ) on the oligomerization of hEC-SOD analyzed by Western blot under native condition. (C) Far-UV circular dichroism of $h E C-S O D^{f}$ and $h E C-S O D^{t r}$ in the presence and absence of $50 \mu \mathrm{M} \mathrm{Cu} / \mathrm{Zn}$. Comparison of $C D$ spectra of $h E C$ $\operatorname{SOD}^{\dagger}(\boldsymbol{\Delta})$ and hEC-SOD ${ }^{\mathrm{tr}}(\Delta)$ in the presence of $50 \mu \mathrm{M} \mathrm{Cu} / \mathrm{Zn}$. (D) hECSOD $^{\text {tr }}$ : free $\Delta, 50 \mu \mathrm{M} Z \mathrm{Zn} \square, 50 \mu \mathrm{M} \mathrm{Cu}$ $\diamond$, and $50 \mu \mathrm{M} \mathrm{Cu} / \mathrm{Zn} O$. (E) hECSOD $^{\text {tr }}$ : free $\Delta, 50 \mu \mathrm{M} Z \mathrm{Zn} \square, 50 \mu \mathrm{M} \mathrm{Cu}$ $\diamond$, and $50 \mu \mathrm{M} \mathrm{Cu} / \mathrm{Zn} \bigcirc$.
MS are shown in Table1. Sequence coverage for hEC-SOD ${ }^{f}$ and $\mathrm{hEC}-\mathrm{SOD}^{\mathrm{tr}}$ were $60 \%$ and $62 \%$, respectively. For hEC$S D^{f}$, several tryptic peptides were obtained, of which peptide 1 (R.AKLDAFFALEGFPTEPNSSSR.A) and peptide 2 (K. LDAFFALEGFPTEPNSSSR.A) showed a molecular weight difference of $0.984 \mathrm{Da}$ after deamidation (Figs. 4A and 4B). Similarly, for hEC-SOD ${ }^{\text {tr }}$, peptide 1 (R.AKLDAFFALEGFPTEPNSSSR.A) and peptide 2 (K.LDAFFALEGFPTEPNSSSR. A) also showed a molecular weight difference of $0.984 \mathrm{Da}$ after deamidation (Figs. 4C and 4D). Table 2 summarizes the tryptic peptide of interest subjected to deamidation for molecular weight calculation. Taken together, this data confirmed that both hEC-SOD ${ }^{f}$ and $h E C-S O D^{\text {tr }}$ were glycosylated at $A s n^{107}$.

\section{DISCUSSION}

The potential of SOD3 as an important therapeutic drug for treating various diseases has been evaluated; however, various limitations have hindered the achievement of a homogenous, active form of hEC-SOD. Here, hEC-SOD was cloned into a pFastBacHTb ${ }^{\text {TM }}$ vector to obtain a (His) $)_{6}$ FLAG taggedPreScission cleavage site-fusion of the hEC-SOD protein. hECSOD protein purified from human aorta has been reported to form stable tetramer as well as octamer (Due et al., 2006). However, it has been reported that hEC-SOD purified from $E$. coli (Bae et. al., 2013) forms octamer in the absence of reduc-
Table 1. Identification of target protein based on LC-MS analysis

\begin{tabular}{ccc}
\hline Details & hEC-SOD & hEC-SOD $^{\text {tr }}$ \\
\hline Nominal mass $\left(\mathrm{M}_{\mathrm{r}}\right)$ & $31835(\mathrm{Da})$ & $30927(\mathrm{Da})$ \\
Sequence coverage & $60 \%$ & $62 \%$ \\
Calculated pl value & 5.71 & 5.72 \\
\hline
\end{tabular}

ing agent. Addition of reducing agent such as DTT drives the formation of tetramer, dimer and monomer. Our result from Sf9 cells also shows hEC-SOD forms octamer in the absence of reducing agent, whereas addition of DTT disrupts oligomer formation, driving to monomer formation. This was confirmed by the analytical size exclusion chromatography (Fig. 2A) and native gel (Fig. 2B). hEC-SOD expressed in eukaryotic Sf9 insect cells might have similar behavior with that purified from $E$. coli.

We have found that hEC-SOD expressed in Sf9 insect cells is glycosylated at $\mathrm{Asn}^{107}$, although the role of this modification is not clear (Liu et al., 2005). The glycosylated form of hEC-SOD is soluble, whereas the unglycosylated form is not, but it can be solubilized by increasing the $\mathrm{pH}$ and ionic strength of the solution (Edlund et al., 1992). LC-MS data revealed that both hECSOD $^{f}$ and hEC-SOD ${ }^{\text {tr }}$ expressed in Sf9 cells are uniformly gly- 
A

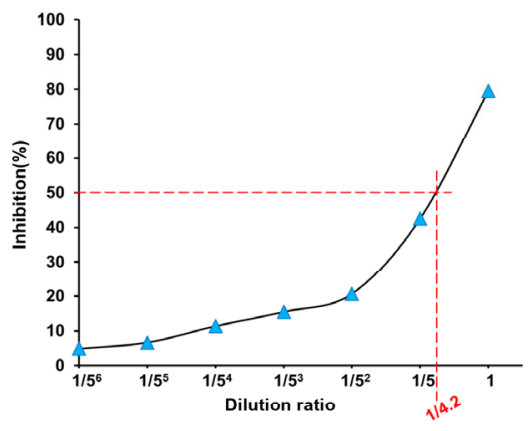

C

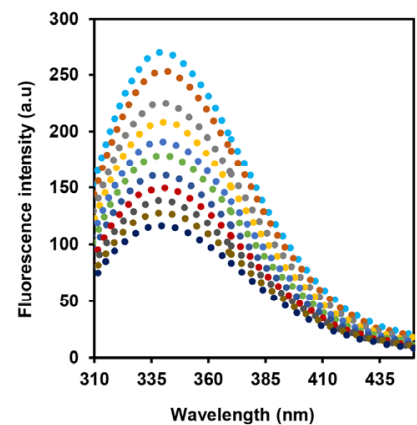

B

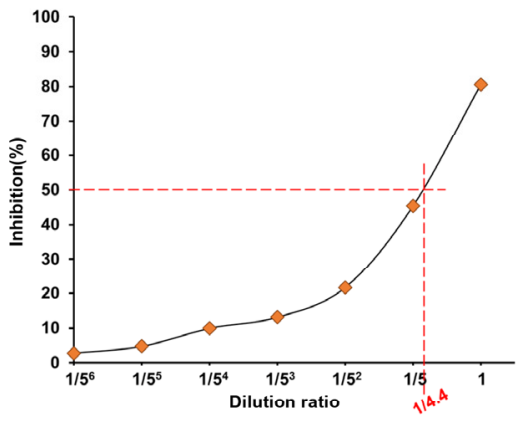

D

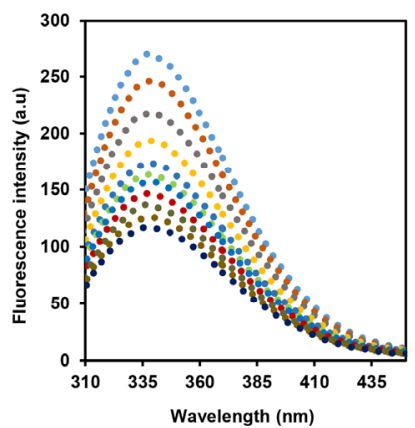

E

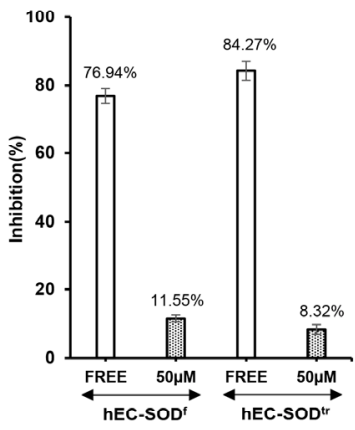

Fig. 3. Enzyme activity and binding affinity of an inhibitor (DDC) of hEC-SOD ${ }^{f}$ and $h E C-S O D^{t}$ in the presence of $0.1 \% B S A \& 50 \mu M$ Cu/Zn. (A) Activity assay of hEC-SOD ${ }^{f}$ in the presence of $0.1 \% \mathrm{BSA}$, and $50 \mu \mathrm{M}$ Cu/Zn ions. (B) Activity assay of hEC-SOD in the presence of $0.1 \%$ BSA, and $50 \mu \mathrm{M} \mathrm{Cu} / \mathrm{Zn}$ ions. (C) Fluorescence assay of hEC-SOD with inhibitor (Na-DDC) in the presence of $0.1 \%$ BSA; $50 \mu \mathrm{M}$ Cu/Zn. (D) Fluorescence assay of hEC-SOD ${ }^{\mathrm{t}}$ with inhibitor (Na-DDC) in the presence of $0.1 \% \mathrm{BSA} ; 50 \mu \mathrm{M} \mathrm{Zn} / \mathrm{Cu}$. Protein samples were excited at $280 \mathrm{~nm}$ and emission spectra were recorded from 300 to $450 \mathrm{~nm}$. All the assays were performed in phosphate-buffered saline (PBS; pH 7.4) using $20 \mu \mathrm{M}$ hEC-

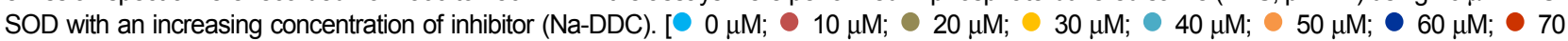
$\mu \mathrm{M} ; \bullet 80 \mu \mathrm{M}$; $90 \mu \mathrm{M}$ and $\bullet 100 \mu \mathrm{M}$. (E) Effect of Na-DDC (inhibitor) on hEC-SOD activity. Enzyme activity of hEC-SOD was determined using the SOD Assay Kit WST-1 (Dojindo Laboratories) in PBS buffer (pH 7.4) in the absence and presence of $50 \mu \mathrm{M}$ of inhibitor (Na-DDC).

A

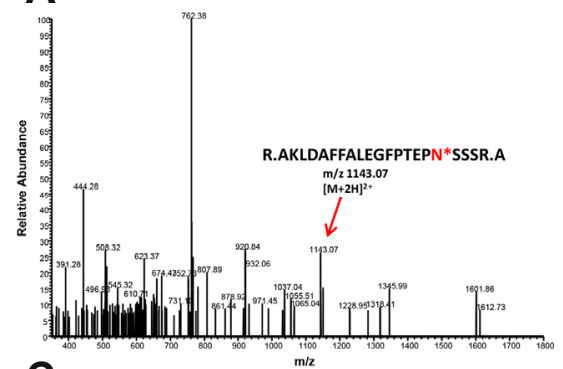

C

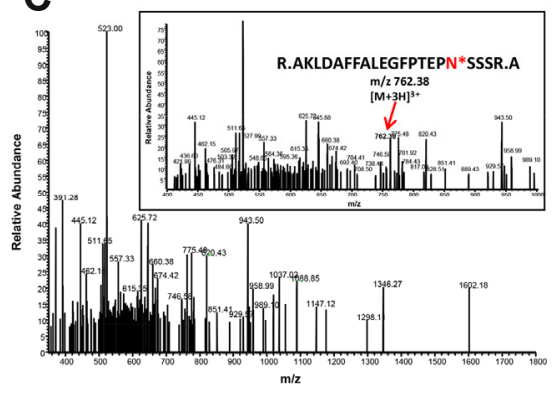

B

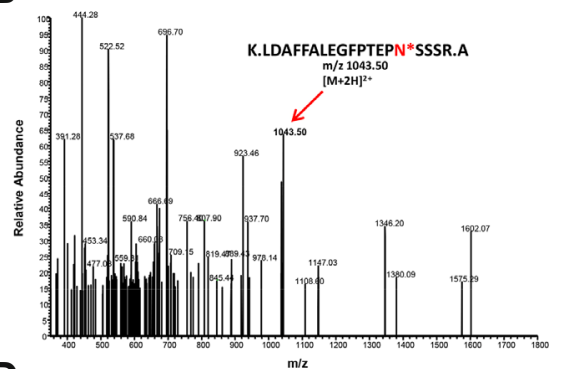

D

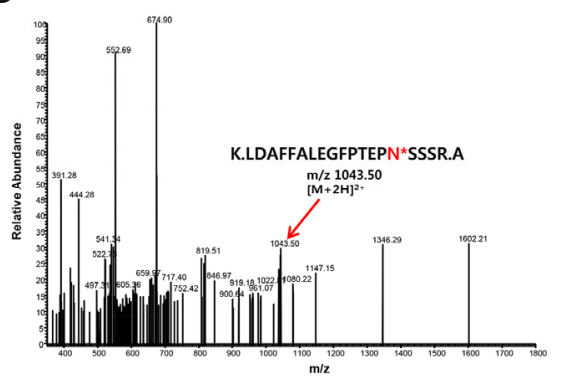

Fig. 4. LC-MS/MS analysis of hEC-SOD and hEC-SOD ${ }^{\text {tr }}$ purified from Sf9 cells. $(A, B)$ Map of hEC-SOD, peptide 1 , and peptide 2 after trypsin cleavage and deamidation. (A) Fragmentation of the lowabundance ion at $\mathrm{m} / \mathrm{z} 1143.07$ resulted in identification of the fully tryptic peptide R.AKLDAFFALEGFPTEPN`SSSR.A. (B) This peptide was identified from the fragmentation of the low-abundance ion at $\mathrm{m} / \mathrm{z} 1043.50$ as the fully tryptic peptide K.LDAFFALEGFPTEPN`SSSR.A. (C, D) Map of hEC-SOD ${ }^{\text {tr }}$, peptide 1 , and peptide 2 after trypsin cleavage and deamidation. (C) Fragmentation of the low-abundance ion at $\mathrm{m} / \mathrm{z} 762.38$ resulted in identification of the fully tryptic peptide R.AKLDAFFALEGFPTEPN`SSSR.A. (D) This peptide was identified from the fragmentation of the low-abundance ion at $\mathrm{m} / \mathrm{z} 1043.50$ as the fully tryptic peptide K.LDAFFALEGFPTEPN`SSSR.A. (Asterisk indicates the $\mathrm{N}$-glycosylation site in each peptide). 
Biochemical Studies on hEC-SOD

Pravesh Shrestha et al.

Table 2. Tryptic peptide molecular weights after deamidation

\begin{tabular}{lllllll}
\hline $\begin{array}{l}\text { Tryptic } \\
\text { peptide }\end{array}$ & hEC-SOD & $\operatorname{Mr}$ (calc) & $\begin{array}{l}\text { lons } \\
\text { Score }\end{array}$ & hEC-SOD & Mr (calc) & $\begin{array}{l}\text { lons } \\
\text { score }\end{array}$ \\
\hline 1 & R.AKLDAFFALEGFPTEPNSSSR.A & 2283.1171 & 104 & R.AKLDAFFALEGFPTEPNSSSR.A & 2283.1171 & 89 \\
& $\begin{array}{l}\text { R.AKLDAFFALEGFPTEPNSSSR.A } \\
\text { (deamidated) }\end{array}$ & 2284.1012 & 91 & $\begin{array}{l}\text { R.AKLDAFFALEGFPTEPNSSSR.A } \\
\text { (deamidated) }\end{array}$ & 2284.1012 & 40 \\
2 & $\begin{array}{l}\text { K.LDAFFALEGFPTEPNSSSR.A } \\
\text { K.LDAFFALEGFPTEPNSSSR.A }\end{array}$ & 2083.9851 & 66 & K.LDAFFALEGFPTEPNSSSR.A & 2083.9851 & 50 \\
& (deamidated) & 2084.9691 & 72 & $\begin{array}{l}\text { K.LDAFFALEGFPTEPNSSSR.A } \\
\text { (deamidated) }\end{array}$ & 2084.9691 & 83 \\
\hline
\end{tabular}

cosylated. DDC, a potent metal ion-chelating agent (Arnelle et al., 1997; lqbal and Whitney, 1991), also inhibited the hECSOD protein purified from Sf9 insect cells (Fig. 3E). We showed that DDC, an inhibitor of superoxide dismutase $(\mathrm{Cu}-\mathrm{ZnSOD}$ and MnSOD), inhibits the activity of hEC-SOD. Possibly, by similar mechanism as in Cu-ZnSOD, hSOD becomes inactive after the removal of copper from Cu-ZnSOD in the presence of DDC (Arnelle et al., 1997; lqbal and Whitney, 1991). However, the detailed binding mode of DDC to superoxide dismutase has unrevealed. We are working on solving crystal structure of hECSOD/DDC complex.

Taken together, we found that both full length and truncated hEC-SOD expressed in Sf9 insect cell possess the native oligomeric conformation, with enzymatic activity, which is essential for developing potent therapeutic hEC-SOD.

\section{ACKNOWLEDGMENTS}

This research was supported by the Bio \& Medical Technology Development Program of the National Research Foundation (NRF) funded by the Ministry of Science, ICT \& Future Planning (NRF2013M3A9A9050577). This work was partially supported by the Brain Korea plus $(\mathrm{BK}+)$ graduate student scholarship program.

\section{REFERENCES}

Antonyuk, S.V., Strange, R.W., Marklund, S.L., and Hasnain, S.S. (2009). The structure of human extracellular copper-zinc superoxide dismutase at $1.7 \AA$ resolution: insights into heparin and collagen binding. J. Mol. Biol. 388, 310-326.

Arnelle, D.R., Day, B.J., and Stamler, J.S. (1997). Diethyl dithiocarbamate-induced decomposition of S-nitrosothiols. Nitric Oxide. 1, 56-64.

Bae, J.Y., Koo, B.K., Ryu, H.B., Song, J.A., Nguyen, M.T., Vu, T.T., Son, Y.J., Lee, H.K., and Choe, H. (2013). Cu/Zn incorporation during purification of soluble human EC-SOD from E. coli stabilizes proper disulfide bond formation. Appl. Biochem. Biotechnol. 169, 1633-1647.

Beyer, W., Imlay, J., and Fridovich, I. (1991). Superoxide dismutases. Prog. Nucl. Acid Res. Mol. Biol. 40, 221-253.

Bowler, R.P., Nicks, M., Warnick, K., and Crapo, J.D. (2002). Role of extracellular superoxide dismutase in bleomycin-induced pulmonary fibrosis. Am. J. Physiol. Lung Cell Mol. Physiol. 282, L719-726.

Bowler, R.P., Nicks, M., Tran, K., Tanner, G., Chang, L.Y., Young, S.K., and Worthen, G.S. (2004). Extracellular superoxide dismutase attenuates lipopolysaccharide-induced neutrophilic inflammation. Am. J. Respir. Cell. Mol. Biol. 31, 432-439.

Byun, S.J., Ji, M.R., Jang, Y.J., Hwang, A.I., Chung, H.K., Kim, J.S., Kim, K.W., Yoo, J.G., and Kim, T.Y. (2013). Human extracellular superoxide dismutase (EC-SOD) expression in transgenic chicken. BMB Rep. 46, 404-409.

Carlsson, L.M., Jonsson, J., Edlund, T., and Marklund, S.L. (1995). Mice lacking extracellular superoxide dismutase are more sensitive to hyperoxia. Proc. Natl. Acad. Sci. USA 92, 6264-6268.
Chen, H.L., Yen, C.C., Tsai, T.C., Yu, C.H., Liou, Y.J., and Lai, Y.W. (2006). Production and characterization of human extracellular superoxide dismutase in the methylotrophic yeast Pichia pastoris. J. Agric. Food Chem. 54, 8041-8047.

Chen, C.M., Lai, Z.L., Yen, C.C., Wang, M.L., and Chen, H.L. (2013). Cloning and expression of the human extracellular superoxide dismutase (EC-SOD) gene in probiotic lactobacillus casei. Int. J. Biosci. Biochem. Bioinforma 3, 557-561.

Demchenko, I.T., Oury, T.D., Crapo, J.D., and Piantadosi, C.A (2002). Regulation of the brain's vascular responses to oxygen. Circ. Res. 91, 1031-1037.

Didion, S.P., Hathaway, C.A., and Faraci, F.M. (2001). Superoxide levels and function of cerebral blood vessels after inhibition of CuZn-SOD. Am. J. Physiol. Heart Circ. Physiol. 281, H1697$\mathrm{H} 1703$.

Due, A.V., Petersen, S.V., Valnickova, Z., Ostergaard, L., Oury, T.D., and Crapo, J.D. (2006). Extracellular superoxide dismutase exists as an octamer. FEBS Lett. 580, 1485-1489.

Edlund, A., Edlund, T., Hjalmarsson, K., Marklund, S.L., Sandstrom, J., Stromqvist, M., and Tibell, L. (1992). A non-glycosylated extracellular superoxide dismutase variant. Biochem. J. 288, 451-456.

Folz, R.J., Abushamaa, A.M., and Suliman, H.B. (1999). Extracellular superoxide dismutase in the airways of transgenic mice reduces inflammation and attenuates lung toxicity following hyperoxia. J. Clin. Invest. 103, 1055-1066.

He, H.J., Yuan, Q.S., Yang, G. Z., and Wu, X.F. (2002). High-level expression of human extracellular superoxide dismutase in Escherichia coli and insect cells. Protein Expr. Purif. 24, 13-17.

Iqbal, J., and Whitney, P. (1991). Use of cyanide and diethyldithiocarbamate in the assay of superoxide dismutases. Free Radic. Biol. Med. 10, 69-77.

Li, J., Li, P.F., Dietz, R., and von Harsdorf, R. (2002). Intracellular superoxide induces apoptosis in VSMCs: role of mitochondrial membrane potential, cytochrome $\mathrm{C}$ and caspases. Apoptosis 7 , 511-517.

Liu, T., Qian, W.J., Gritsenko, M.A., Camp 2nd, D.G., Monroe, M.E., Moore R.J., and Smith, R.D. (2005). Human plasma Nglycoproteome analysis by immunoaffinity subtraction, hydrazide chemistry, and mass spectrometry. J. Proteome Res. 4, 20702080.

Mamo, L.B., Suliman, H.B., Giles, B.L., Auten, R.L., Piantadosi, C.A., and Nozik-Grayck, E. (2004). Discordant extracellular superoxide dismutase expression and activity in neonatal hyperoxic lung. Am. J. Respir. Crit. Care Med. 170, 313-318.

Nozik-Grayck, E., Suliman, H.B., and Piantadosi, C.A. (2005). Extracellular superoxide dismutase. Int. J. Biochem. Cell Biol. 37, 2466-2471.

Ohta, H., Adachi, T., and Hirano, K. (1994). Internalization of human extracellular- superoxide dismutase by bovine aortic endothelial cells. Free Rad. Biol. Med. 16, 501-507.

Oury, T.D., Day, B.J., and Crapo, J.D. (1996a). Extracellular superoxide dismutase: a regulator of nitric oxide bioavailability. Lab. Invest. $75,617-636$.

Oury, T.D., Day, B.J., and Crapo, J.D. (1996b). Extracellular superoxide dismutase in vessels and airways of humans and baboons. Free Radic. Biol. Med. 20, 957-965.

Oury, T.D., Schaefer, L.M., Fattman, C.L., Choi, A., Weck, K.E., and Watkins, S.C. (2002). Depletion of pulmonary EC-SOD after ex- 
posure to hyperoxia. Am J. Physiol. Lung Cell Mol. Physiol. 283, L777-784.

Petersen, S.V., Olsen, D.A., Kenney, J.M., Oury, T.D., Valnickova, Z., Thogersen, I.B., Crapo, and J.D., Enghild, J.J. (2005). The high concentration of $\mathrm{Arg}^{213} \rightarrow$ Gly extracellular superoxide dismutase (EC-SOD) in plasma is caused by a reduction of both heparin and collagen affinities. Biochem. J. 385, 427-432.

Ryu, K., Kim, Y.H., Lee, J.S., Jeon, B., Kim, and T.Y. (2008). Increased yield of high-purity and active tetrameric recombinant human EC-SOD by solid phase refolding. J. Microbiol. Biotechnol. $18,1648-1654$.

Suliman, H.B., Ali, M., and Piantadosi, C.A. (2004). Superoxide dismutase-3 promotes full expression of the EPO response to hypoxia. Blood 104, 43-50.

Tan, A.S., and Berridge, M.V. (2000). Superoxide produced by activated neutrophils efficiently reduces the tetrazolium salt, WST-1 to produce a soluble formazan: a simple colorimetric assay for measuring respiratory burst activation and for screening anti- inflammatory agents. J. Immunol. Methods 238, 59-68.

Tan, R.J., Fattman, C.L., Watkins, S.C., and Oury, T.D (2004). Redistribution of pulmonary EC-SOD after exposure to asbestos. J. Appl. Physiol. 97, 2006-2013.

Tibell, L., Hjalmarsson, K., Edlund, T., Skogman, G., Engstrom, V., and Marklund, S.L. (1987). Expression of human extracellular superoxide dismutase in Chinese hamster ovary cells and characterization of the product. Proc. Natl. Acad. Sci. USA 84, 66346638.

Yun, J.H., Kim, K., Jung, Y., Park, J.H., Cho H.S., and Lee, W. (2015). Co-expression of human agouti-related protein enhances expression and stability of human melanocortin-4 receptor. Biochem. Biophys. Res. Commun. 456, 116-121.

Zelko, I.N., Mariani, T.J., and Folz, R.J. (2002). Superoxide dismutase multigene family: a comparison of the CuZn-SOD (SOD1), Mn-SOD (SOD2), and EC-SOD (SOD3) gene structures, evolution, and expression. Free Radical. Biol. Med. 33, 337-349. 